\title{
POLA KEMITRAAN PEMASARAN LOBSTER DI KOTA BENGKULU
}

\section{(PARTNERSHIP PATTERN IN MARKETING OF LOBSTER IN BENGKULU CITY)}

\author{
M. Mustopa Romdhon \\ Ketut Sukiyono \\ Jurusan Sosial Ekonomi Pertanian \\ Fakultas Pertanian \\ Universitas Bengkulu \\ Email: abyaz_75@yahoo.co.id; ksukiyono@yahoo.com
}

\begin{abstract}
Relationship among lobster marketing agents could determine partnership pattern, but how the relationship was build and run, its need depth explanation. The research was aims to synthesize partnership pattern, rights and obligations among agents under lobster marketing at Bengkulu Municipal. The Partnership pattern was explained descriptively through non-contractual, equipment and capital achieved. The research was employed at North Bengkulu Districts at three villages (Pasar Pedati, Pasar Ketahun and Pasar Seblat). They were biggest lobster supplier to the UD. Edi Koto. Respondents were fisherman under an unit fishing boat (32 unit) and 12 traders. The results showed that partnership pattern among agents were KOA and Dagang Umum where was KOA more dominant than dagang umum and its profitable.
\end{abstract}

Key words: partnership system, marketing, lobster

\section{PENDAHULUAN}

Lobster termasuk salah satu jenis komoditi perikanan yang memiliki nilai ekonomi yang tinggi. Harga lobster di pasar domestik maupun internasional menunjukkan peningkatan sangat menguntungkan bagi nelayan dan juga pelaku usaha pemasaran lobster di Kota Bengkulu. Terbatasnya penguasaan aset baik itu teknologi maupun permodalan diduga menyebabkan belum optimalnya penangkapan lobster bahkan beberapa tahun terakhir ini produksi lobster di Bengkulu cenderung konstan.Lobster merupakan komoditi yang diminta dalam kondisi hidup. Lobster memiliki sifat yang mudah rusak membutuhkan penanganan dengan sistem rantai dingin. Rumitnya proses penanganan pemasaran lobster dan alur distribusi pemasaran yang panjang menyebabkan nelayan kesulitan menangani proses pengolahan dan pemasaran lobster sampai kepada tangan konsumen.

Nelayan pada umumnya adalah nelayan tradisional yang memiliki peralatan melaut dengan teknologi sederhana serta modal terbatas. Dampaknya nelayan harus bergantung kepada pemilik modal serta penguasa teknologi dan 
pasar yaitu pedagang. Untuk menjamin keberlanjutan hubungan yang saling menguntungkan antara nelayan dan pedagang kedua pelaku usaha ini mengikat diri dalam sistem kemitraan usaha pemasaran lobster. Kemitraan ini bertujuan untuk mencegah praktek eksploitasi oleh pedagang kepada nelayan seperti yang umumnya dialami oleh nelayan di tempat lain.

Kemitraan juga terjalin antara pedagang pengumpul dengan perusahaan, karena pedagang pengumpul juga memiliki keterabatasan aksesibilitas ke pasar lobster. Hubungan kemitraan ini dibangun untuk memperoleh jaminan pasar serta harga yang lebih baik serta jaminan pasokan lobster bagi perusahaan Bagaimana jalinan kemitraan diantara pelaku usaha pemasaran lobster, terkait dengan itu dalam tulisan ini akan dijelaskan bentuk kemitraan, hak dan kewajiban antara pedagang pengumpul yang menjual lobster kepada UD Edi Koto dengan nelayan lobster serta antara pedagang pengumpul dengan UD Edi Koto dalam pemasaran lobster di Kota Bengkulu?

\section{KERANGKA TEORETIS}

Bentuk jalinan kerjasama produksi dalam pemasaran lobster di Kota Bengkulu ditelaah berdasarkan konsep kemitraan yang dicanangkan oleh pemerintah setelah berlakunya UU No. 9/1995 tentang usaha kecil dan Inpres No.10 Tahun 1998 tentang usaha menengah. Menurut UU. NO. 9/1995 tentang UKM (Hafsah,1999) kemitraan didefinisikan sebagai kerjasama antara usaha kecil dengan usaha menengah dan atau usaha besar dengan memperhatikan prinsip saling memerlukan, saling memperkuat, dan saling menguntungkan. Sedangkan kemitraan juga didefinisikan sebagai suatu strategi bisnis yang dilakukan dua pihak atau lebih, dalam jangka waktu tertentu untuk meraih keuntungan bersama dengan prinsip saling membutuhkan dan saling membesarkan (Hafsah, 2002). Dalam sistem agribisnis di Indonesia dikenal beberapa pola kemitraan dimana pola kemitraan usaha ini menurut (Saptana dan Ashari,2007) akan menjamin keberlanjutan sutau usaha agribisnis yaitu 1. Pola kemitraan inti-plasma, 2. Pola kemitraan subkontrak, 3. Pola kemitraan dagang umum, 4. Pola kemitraan keagenan, 5. Pola kemitraan kerja sama operasional agribisnis (KOA). Kelima pola kemitraan ini secara umum harus memiliki 8 unsur menurut Brinkerhoff et al (1990) dalam Sumardjo et al (2004), kedelapan unsur tersebut antara lain:

1. Input (sumber daya), yaitu material, uang, manusia, informasi, dan pengetahuan merupakan hal yang didapat dari lingkungannya dan akan memiliki kontribusi pada produksi output. Input memiliki peran yang penting dalam terlaksananya proses kemitraan. Pada sektor agribisnis input dapat berupa biaya operasional, biaya pemasaran, biaya tenaga kerja dan sebagainya. Dalam suatu proses kemitraan misalnya antara petani dengan perusahaan, pada umumnya terdapat kondisi dimana petani tidak mampu menyediakan input produksi yang dibutuhkan sehingga diperlukannya 
kehadiran suatu badan usaha seperti perusahaan yang mau bermitra dengan mereka sehingga kebutuhan input dapat terpenuhi.

2. Output, seperti produk dan pelayanan adalah hasil dari suatu kelompok atau organisasi. Sebagai contoh pada sektor perkebunan kelapa sawit kemitraan antara perusahaan dengan petani dapat menghasilkan output berupa tandan buah segar.

3. Teknologi, metode, dan proses dalam transformasi input menjadi output. Ini merupakan unsur yang berperan dalam mendukung terjalinnya kemitraan dengan lancar. Dengan teknologi yang memadai maka output yang dihasilkan dapat diupayakan memiliki nilai tambah.

4. Lingkungan, yaitu keadaan di sekitar kelompok mitra dan perusahaan mitra yang dapat mempengaruhi jalannya kemitraan. Kondisi lingkungan yang aman dan terkendali sangat mendukung lancarnya jalinan kemitraan.

5. Keinginan,yaitu strategi, tujuan, rencana dari pengambil keputusan. Keinginan ini harus berasal dari semua pihak bermitra. Keinginan yang betekad untuk maju akan mendorong terjalinnya kemitraan dengan lancar.

6. Perilaku dan proses, yaitu pola perilaku, hubungan antar kelompok atau organisasi dalam proses kemitraan.

7. Budaya,yaitu norma, kepercayaan, dan nilai dalam kelompok mitra dan perusahaan mitra.

8. Struktur,yaitu hubungan antar -indivudu, kelompok, dan unit yang lebih besar.

Kedelapan unsur tersebut merupakan unsur-unsur yang saling terkait. Faktor-faktor internal menentukan untuk pengembangan agribisnis perikanan menurut Susilawati (2005), yaitu : (1) potensi sumberdaya ikan laut; (2) ketersediaan tenaga kerja; (3) koordinasi antar instansi terkait; (4) dukungan kebijakan Pemda; (5) program bantuan pemda yang mendukung. Sedangkan faktor-faktor kelemahannya adalah : (1) rendahnya kualitas SDM aparat dan nelayan; (2) sarana penangkapan masih bersifat tradisional; (3) teknologi pengolahan bersifat tradisional; (4) kualitas produk rendah; (5) kurangnya cabang Dinas Kelautan dan Perikanan tingkat kecamatan serta kelompok dan koperasi nelayan yang belum berfungsi secara optimal; (6) ketersediaan modal usaha terbatas; (7) sistem pemasaran lemah; (8) sarana prasarana pendukung perikanan tangkap kurang memadai.

Besar kecilnya input yang diberikan akan sangat berpengaruh terhadap output yang dihasilkan. Tetapi out put yang dihasilkan tentunya sangat dipengaruhi juga oleh kondisi lingkungan disekitar input dengan tidak tidak terlepas dari kepemilikan teknologi yang mendukung. Hal lain yang berada di luar proses seperti keinginan, budaya, perilaku tentunya sedikit banyak akan berpengaruh terhadap kemitraan. Selanjutnya struktur kemitraan yang dijalin juga berpengaruh terhadap besar kecilnya output yang dihasilkan. Relasi antar nelayan dan perusahaan yang tercermin dalam bentuk hak dan kewajiban di analisa berdasarkan konsep kemitraan menurut ketentuan pemerintah (ketetapan menteri pertanian). 


\section{METODE PENELITIAN}

Penelitian ini dilakukan di Kabupaten Bengkulu Utara pada tiga lokasi pendaratan kapal yaitu Desa Pasar Pedati, Pasar Ketahun dan Pasar Seblat. Pemilihan desa-desa ini karena wilayah ini merupakan pemasok lobster terbesar pada UD Edi Koto Bengkulu serta sentra pendaratan kapal bagi nelayan lobster. Responden dalam penelitian ini adalah kelompok nelayan dalam satu unit kapal tangkap dan pedagang pengumpul. Pengambilan responden dalam penelitian ini dilakukan berdasarkan sensus terhadap 12 pedagang pengumpul dan 67 unit kapal tangkap. Model kemitraan dianalisa secara deskriptif sehingga diperoleh penjelasan tentang pola hubungan kontrak, sarana dan prasarana dan permodalan yang didapat dari jalinan kemitraan.

\section{HASIL DAN PEMBAHASAN}

\section{Proses Terbentuknya Kemitraan}

Usaha jual beli lobster antara nelayan dengan pedagang pengumpul terjalin dalam bentuk kerjasama melalui pengaturan yang disesuaikan dengan kebutuhan masing-masing pihak. Selanjutnya aturan main yang telah disepakati tersebut oleh masing-masing pihak didasarkan atas manfaat yang berkelanjutan (Suradisastra, 1999). Kerjasama antara nelayan dengan pedagang atau kemitraan pada dasarnya diangkat dari pola kemitraan tradisional. Menurut Kasryno dan Pranaji (1984) saat ini telah terindentifikasi tiga pola kemitraan pada kegiatan agribisnis, yaitu pola kemitraan tradisional, pola kemitraan pemerintah dan pola kemitraan pasar. Salah satu ciri pola kemitraan tradisional dalam pemasaran lobster yaitu tidak adanya kontrak yang jelas antara nelayan dengan pedagang dalam melakukan kerjasama.

Kerjasama yang terjalin antara nelayan dengan pedagang mencakup mulai dari pengadaan armada tangkap, alat tangkap, penanganan biaya operasional dan tentunya sampai pada proses pemasaran. Hasil penelitian menunjukkan bahwa kerjasama yang terjalin antara nelayan dengan pedagang telah terjalin lama (rata-rata 4,09 tahun), tapi kerjasama ini tidak bersifat permanen, sehingga nelayan dapat berkerjasama dengan pedagang yang berbeda secara bergantian. Ada kalanya selama beberapa tahun bekerjasama dengan pedagang A, tetapi pada tahun berikutnya beralih bemitra dengan pedagang B. Lama tidaknya nelayan bekerjasama dengan pedagang dapat dipengaruhi oleh beberapa faktor antara lain: lama pedagang bersangkutan berdagang lobster, hak dan kewajiban dalam bermitra, jumlah pedagang lain yang berpengaruh pada alternatif pilihan bagi nelayan serta pola kerjasama yang dianut akan sangat berpengaruh pada bentuk hak dan kewajiban yang diperoleh oleh nelayan maupun pedagang. Setiap bantuan (teknologi tangkap, modal ) yang diberikan pedagang mempengaruhi aturan main yang diberlakukan. 
Hasil penelitian menunjukkan bahwa nelayan rata-rata lama telah bekerjasama dengan pedagang mencapai 4 tahun lebih. Pada umumnya jika sudah berkerjasama dengan seorang pedagang, nelayan tidak akan berpindah kepada pedagang pengumpul lain. Hal tersebut terjadi pada nelayan mitra maupun nelayan non mitra. Fenomena ini terjadi karena umumnya antara pedagang dengan nelayan sudah ada keterikatan sosial yang membentuk unsur kepercayaaan yang erat dan susah untuk dipisahkan. Kemungkinan yang muncul bahwa nelayan dapat berpindah pada pedagang lain bilamana nelayan berhenti untuk beberapa lama kemudian melaut kembali dan berganti mitra dengan pedagang pengumpul lain. Proses bermitra antara nelayan dengan pedagang sangat terkait dengan rangkaian proses yang terjadi diantara kedua belah pihak baik sebelum terbentuk ataupun selama kemitraan terjalin. Proses yang berlangsung selama kemitraan dijalin sangat berkaitan dengan pola penentuan hak dan kewajiban yang diterima masing-masing pihak.

Kemitraan yang berlangsung antara nelayan dengan pedagang merupakan pola kemitraan yang masih bersifat tradisional. Dikatakan tradisional karena kemitraan yang terbentuk terjadi tanpa adanya kesepakatan tertulis sebelum memulai. Hal-hal yang terkait dengan aturan main dalam kemitraan disepakati hanya dengan menggunakan asas kepercayaan satu sama lain. Nelayan memiliki ketrampilan dalam menangkap lobster, tetapi mereka umumnya memiliki keterbatasan sumberdaya modal serta akses pasar, atau nelayan memiliki sumberdaya tetapi terbatas dalam akses pasar. Di sisi lain pedagang terbatas dalam hal sumberdaya kerja, tetapi memiliki kemampuan modal yang jauh lebih dari nelayan sehingga mereka sanggup untuk melengkapi kekurangan dari nelayan. Selain itu pedagang memiliki akses pasar lobster. Adanya asas kepercayaan akhirnya membuat pedagang mau melepas modalnya kepada nelayan berupa sarana prasarana penangkapan. Melalui pertemuan antara perbedaan kemampuan penyediaan sumber daya inilah yang menyebabkan terbentuknya kemitraan.

\section{Hak dan Kewajiban dalam Bermitra}

Hak dan kewajiban merupakan hal penting yang harus diperhatikan dalam melakukan kemitraan. Dalam usaha tangkap lobster hak yang diterima oleh nelayan merupakan kewajiban yang harus dipenuhi oleh pedagang begitu juga sebaliknya. Oleh sebab itu bentuk pola kemitraan dapat diidentifikasi melalui jenis hak dan kewajiban yang ada pada masing-masing pihak yang bermitra.

Hak dan kewajiban yang terdapat dalam pola kemitraan yang dijalin oleh nelayan dan pedagang merupakan hasil kesepakatan dua belah pihak yang disepakati hanya secara lisan tanpa bukti tertulis. Hal ini didasari oleh karena adanya sistem saling percaya satu sama lain. Hak atau input yang diterima oleh nelayan terdiri dari armada tangkap (perahu, mesin), alat tangkap (jaring), bahan bakar serta jaminan lobster selalu dibeli atau dalam kata lain bantuan penjualan. Sebaliknya, kewajiban yang harus dipenuhi nelayan kepada pedagang adalah selalu memasok lobster. Praktek pemberian hak kepada 
nelayan berbeda satu sama lain. Ada nelayan yang memperoleh semua jenis input, tetapi ada juga yang tidak. Perbedaan ini dapat terjadi karena kemampuan modal pedagang berbeda sehingga input yang diberikan berbeda pula. Selain itu, beberapa nelayan sudah memiliki sebagian input sehingga nelayan akan menggunakan input yang masih belum dimilikinya. Pembagian hak dan kewajiban antara nelayan dengan pedagang dapat dilihat pada Tabel 1.

\section{Hak Nelayan dan Pedagang Pengumpul dalam Bermitra}

Hak yang diterima oleh nelayan merupakan masukan input yang diberikan oleh pedagang. Pedagang pengumpul memiliki hak menerima pasokan lobster dan atau pembayaran sewa atas input yang sudah dipakai oleh nelayan. Kebutuhan Input nelayan (perahu, mesin, jaring, bahan bakar) sangat ditentukan oleh kelengkapan armada dan peralatan tangkap yang dimiliki. Oleh sebab itu jenis input yang diterima tiap nelayan berbeda. Nelayan juga memperoleh hak berupa bantuan penjualan. Jika nelayan menggunakan input dari pedagang maka mereka wajib membayar biaya sewa. Selanjutnya jika nelayan memiliki input sendiri maka mereka tidak perlu lagi membayar biaya sewa yang diperhitungkan sesuai dengan persentase bagi hasil. Input yang dimiliki nelayan ada kalanya diperoleh dengan membeli secara kredit dari pedagang. Jika pembelian dilakukan secara kredit maka ketentuan cicilan serta jangka waktu pembayaran tidak jelas, sehingga menimbulkan perilaku curang (moral hazard). Berdasarkan kategori bantuan yang diterima maka pola kemitraan ini dapat dikelompokkan atas tiga pola bantuan umum yaitu :

\section{a. Perahu, Mesin, Jaring, Bahan Bakar, Bantuan Penjualan}

Banyaknya jumlah input yang diterima menjadi indikator kepemilikan aset nelayan. Sedangkan banyaknya input yang diberikan menunjukkan kekuatan aset pedagang. Nelayan yang menerima input ini adalah nelayan yang sama sekali tidak memiliki peralatan tangkap serta tidak mampu membeli bahan bakar sendiri sehingga mereka menggunakan semua milik pedagang. Dengan kata lain nelayan tipe ini adalah nelayan yang tidak memiliki modal sama sekali. Persentase nelayan yang memilih pola bantuna relative besar $37,50 \%$. Pola ini tersebar di wilayah Pasar Pedati dan Pasar Ketahun serta di Pasar Ketahun. Dengan pola ini nelayan sangat tergantung kepada pedagang pengumpul. Selain itu diduga daya beli nelayan mitra terhadap armada dan peralatan tangkap masih cukup rendah

\section{b. Mesin, Bahan Bakar, Bantuan Penjualan}

Persentase nelayan menggunakan mesin dan bahan bakar bantuan pedagang pengumpul sebesar 9,38\%. Fenomena ini berlangsung pada nelayan nelayan di daerah Pasar Ketahun. Kedua jenis bantuan ini menyerap ongkos produksi besar. Investasi kapal tangkap yang cukup besar sehingga tidak semua nelayan memiliki dana untuk membelinya secara mandiri. Fluktuasi harga bahan bakar minyak sangat menentukan frekuensi dan jangkau tangkap nelayan. 
Tabel 1. Pembagian Hak dan Kewajiban Antara Nelayan dengan Pedagang

\begin{tabular}{|c|c|c|c|c|}
\hline \multirow{2}{*}{ No } & \multirow{2}{*}{ Pelaku } & \multicolumn{3}{|c|}{ Kombinasi Alternatif Hak dan Kewajiban } \\
\hline & & Alternatif Hak & & Alternatif Kewajiban \\
\hline \multirow[t]{8}{*}{1} & Nelayan & $\begin{array}{l}\text { a. Perahu, mesin, jaring, } \\
\text { bahan bakar, bantuan } \\
\text { penjualan. }\end{array}$ & $><$ & $\begin{array}{l}\text { Biaya sewa, memasok } \\
\text { lobster. }\end{array}$ \\
\hline & & $\begin{array}{l}\text { b. Perahu, mesin ,bahan } \\
\text { bakar, bantuan } \\
\text { penjualan. }\end{array}$ & $><$ & $\begin{array}{l}\text { Biaya sewa, memasok } \\
\text { lobster. }\end{array}$ \\
\hline & & $\begin{array}{l}\text { c. Perahu, mesin, bantuan } \\
\text { penjualan. }\end{array}$ & $><$ & $\begin{array}{l}\text { Biaya sewa, memasok } \\
\text { lobster. }\end{array}$ \\
\hline & & $\begin{array}{l}\text { d. Mesin, bahan bakar, } \\
\text { bantuan penjualan. }\end{array}$ & $><$ & $\begin{array}{l}\text { Biaya sewa, memasok } \\
\text { lobster. }\end{array}$ \\
\hline & & $\begin{array}{l}\text { e. Jaring, bahan bakar, } \\
\text { bantuan penjualan. }\end{array}$ & $><$ & $\begin{array}{l}\text { Biaya sewa, memasok } \\
\text { lobster. }\end{array}$ \\
\hline & & $\begin{array}{l}\text { f. Perahu, bantuan } \\
\text { penjualan. }\end{array}$ & $><$ & $\begin{array}{l}\text { Biaya sewa, memasok } \\
\text { lobster. }\end{array}$ \\
\hline & & $\begin{array}{l}\text { g. Jaring, bantuan } \\
\text { penjualan. }\end{array}$ & $><$ & $\begin{array}{l}\text { Biaya sewa, memasok } \\
\text { lobster. }\end{array}$ \\
\hline & & $\begin{array}{l}\text { h. Hanya bantuan } \\
\text { penjualan. }\end{array}$ & $><$ & Memasok Lobster. \\
\hline \multirow[t]{8}{*}{2} & $\begin{array}{l}\text { Pedagang } \\
\text { Pengumpul }\end{array}$ & a. Sewa, pasokan lobster & $><$ & $\begin{array}{l}\text { Menyediakan perahu, } \\
\text { mesin, jaring, bahan } \\
\text { bakar \& bantuan } \\
\text { penjualan. }\end{array}$ \\
\hline & & b. Sewa, pasokan lobster & $><$ & $\begin{array}{l}\text { Menyediakan } \\
\text { perahu,mesin, bahan } \\
\text { bakar \& bantuan } \\
\text { penjualan }\end{array}$ \\
\hline & & c. Sewa, pasokan lobster & $><$ & $\begin{array}{l}\text { Menyediakan perahu, } \\
\text { mesin, bantuan } \\
\text { penjualan. }\end{array}$ \\
\hline & & d. Sewa, pasokan lobster & $><$ & $\begin{array}{l}\text { Menyediakan mesin, } \\
\text { bahan bakar \& } \\
\text { bantuan penjualan. }\end{array}$ \\
\hline & & f. Sewa, pasokan lobster & $><$ & $\begin{array}{l}\text { Menyediakan jaring, } \\
\text { bahan bakar \& } \\
\text { bantuan penjualan. }\end{array}$ \\
\hline & & g. Sewa, pasokan lobster & $><$ & $\begin{array}{l}\text { Menyediakan perahu, } \\
\text { bantuan penjualan }\end{array}$ \\
\hline & & h. Sewa,pasokan lobster & $><$ & $\begin{array}{l}\text { Menyediakan jaring, } \\
\text { bantuan penjualan }\end{array}$ \\
\hline & & i. Pasokan lobster & $><$ & Membantu penjualan \\
\hline
\end{tabular}

Sumber: Data Primer Diolah, 2008

132 | M. Mustopa Romdhon dan Ketut Sukiyono. Pola Kemitraan Pemasaran Lobster... 


\section{b. Bantuan Penjualan}

Semua nelayan yang memperoleh input berupa armada tangkap, alat tangkap dan atau bahan bakar secara otomatis akan mendapatkan bantuan penjualan. Namun ada pula nelayan yang hanya memperoleh hak bantuan penjualan. Nelayan mampu menyediakan sendiri seluruh sarana dan prasarana penangkapan melalui dukungan permodalan mandiri secara layak. Nelayan mitra yang memilih hak ini hanya berasal dari wilayah Pasar Pedati. Hal ini menunjukkan bahwa kemampuan permodalan nelayan mitra di wilayah Pasar Pedati dan Pasar Ketahun masih lebih rendah hal ini berdampak pada tingkat ketergantungan nelayan kepada pedagang lebih besar.

\section{Kewajiban Nelayan dan Pedagang Pengumpul dalam Bermitra}

Kewajiban dari nelayan merupakan hak yang akan diterima oleh pedagang. Kembali ditegaskan bahwa hak dan kewajiban dalam bermitra tidak disepakati secara tertulis sehingga tidak akan memiliki kekuatan hukum yang kuat. Ada dua alternatif kewajiban yang harus dipenuhi oleh nelayan kepada pedagang sebagai konsekuensi atas hak yang sudah diterima dari pedagang pengumpul. Nelayan yang memperoleh hak dari pedagang mitranya maka mereka wajib membayar biaya sewa atas penggunaan input serta berkewajiban memasok lobster kepada pedagang pengumpul. Biaya sewa diperoleh dari besarnya persentase bagi hasil dikalikan dengan besarnya penerimaan dikurangi biaya operasional.

Sedangkan nelayan yang harus memenuhi kewajiban memasok lobster merupakan nelayan yang sama sekali tidak menggunakan input dari pedagang. Kewajiban yang harus dipenuhi oleh nelayan pada dasarnya hanyalah memasok lobster dan atau membayar biaya sewa. Tetapi pemberlakuan kewajiban ini akan berbeda di masing-masing daerah. Dengan demikian dapat disimpulkan bahwa semua nelayan mitra di kedua daerah ini masih bergantung kepada pedagang dalam penyediaan input.

\section{Pola Kemitraan}

Bentuk kegiatan dalam kemitraan antara nelayan dengan pedagang menjadi pertimbangan dalam menentukan pola kemitraan yang sedangkan berlangsung. Pola kemitraan bersifat spesifik lokasi. Hal ini menurut Darwis (2006) terjalin karena adanya kebutuhan bersama antar pelaku usaha. Bentuk kegiatan tersebut berkaitan dengan pola penentuan harga dan pola bagi hasil.

\section{Pola Penentuan Harga dan Bagi Hasil}

Dua pola penetapan harga penjualan lobster di tingkat nelayan. Harga tipe 1 mengikuti beberapa prinsip antara lain: 1). Harga ditentukan secara sepihak oleh pedagang, 2). Harga ditentukan dengan merespon sinyal harga dari UD Edi Koto atau merespon sinyal harga dari perusahaan lain, 3). Sinyal harga dari Edi Koto atau perusahaan lain menunjukkan harga naik, perubahan harga relatif lambat direspon oleh pedagang. Sebaliknya saat harga turun maka harga beli kepada nelayan akan cepat berubah turun. Sedangkan harga tipe 2 masih 
mengikuti prinsip yang sama dengan pola penentuan harga pada tipe 1. Hal yang membedakan adalah harga tipe 2 ditentukan dengan selisih sebesar Rp.5.000/kg lebih rendah dari harga pada tipe 1. Harga ini berlaku untuk nelayan yang membeli jaring secara kredit dari pedagang. Selisih harga sebesar Rp.5.000/kg merupakan konsekuensi atas pembelian jaring secara kredit yang terpisah dari cicilan atas pembayaran kredit jaring. Pola penentuan harga yang terjadi belum mencerminkan suatu pola kemitraan usaha bersifat partisipatif. Hal ini menurut Saptana dan Ashari (2007) menyebabkan tingkat efisiensi dan pertumbuhan usaha pemasaran lobster yang rendah.

Hasil penelitian menunjukkan bahwa rata-rata harga tertinggi dari pedagang pengumpul untuk pedagang diterima nelayan pada lokasi-lokasi yang lebih dekat jaraknya dengan perusahaan penampung lobster (seperti nelayan di Pasar Pedati). Jarak relatif dekat dengan menyebabkan ongkos transportasi yang dikeluarkan lebih kecil dibandingkan ketiga daerah lain. Disamping itu resiko kematian lobster selama proses pengiriman juga rendah, sehingga harga yang ditawarkan pada nelayan lebih tinggi. Sebaliknya, harga terendah diterima nelayan dengan lokasi lebih jauh dari lokas perusahaan (seperti nelayan di Pasar Seblat).

Pola bagi hasil dalam kemitraan pemasaran lobster terbagi dua yaitu pola bagi hasil 1:1 dan Pola 1:N. Pola bagi hasil ini sangat ditentukan oleh jumlah input yang diberikan. Kombinasi input yang semakin lengkap akan mengarah pada pola bagi hasil 1:1. Artinya setiap penerimaan yang diperoleh akan dibagi 2 (50\%: 50\%) antara satuan unit tangkap dengan pedagang. Penerimaan yang dimaksud adalah besarnya nilai penjualan tunai lobster nelayan kepada pedagang yang bersangkutan pada saat nelayan menjual lobster yang didapat sepulang dari melaut. Pada sistem bagi hasil 1:1 seluruh biaya (biaya operasional, biaya perawatan dan penyusutan perahu, mesin, jaring dan peralatan tangkap lainnya) ditanggung oleh pedagang. Ketika biaya operasional tidak dapat tertutupi dalam satu kali penangkapan maka biaya akan dibebankan untuk penangkapan selanjutnya. Input yang diberikan pedagang bukan menjadi hak milik nelayan melainkan tetap milik pedagang. Sistem bagi hasil ini menandakan bahwa nelayan tidak memiliki aset sama sekali sehingga mereka hanya memberikan kontribusi berupa tenaga kerja.

Sistem bagi hasil 1: $\mathrm{N}$ mengandung arti bahwa setiap penerimaan dari usaha tangkap lobster sebesar 1 bagian harus diberikan kepada pedagang yang telah memberikan input dan $\mathrm{N}$ bagian menjadi milik nelayan. Dalam pola bagi hasil 1: $\mathrm{N}$ penerimaan adalah besarnya nilai penjualan tunai lobster nelayan kepada pedagang dikurangkan dengan biaya operasional. Sama seperti pola 1:1, input yang diberikan oleh pedagang tidak menjadi hak milik nelayan melainkan tetap milik pedagang sehingga biaya penyusutan dan biaya perawatan menjadi beban pedagang.

Berdasarkan pola penentuan harga, dan pola bagi hasil dalam kemitraan pemasaran lobster di tingkat nelayan maka dapat ditentukan pola kemitraan kemitraan yang dianut. Ada beberapa jenis pola kemitraan yakni pola inti 
plasma, pola sub kontrak, pola dagang umum, pola keagenan, pola kerjasama operasional agribisnis (KOA).

\section{Pola Kemitraan Kerjasama Operasional Agribisnis (KOA)}

Suatu hubungan kemitraan dapat dikatakan sebagai bentuk pola kemitraan Kerjasama Operasional Agribisnis (KOA) jika memenuhi kriteria sebagai berikut:

\section{a. Pedagang Memiliki Kewajiban}

- Menyediakan biaya, modal dan manajemen

- Mengadakan sarana prasaran penangkapan lobster

- Sebagai penjamin pasar lobster

- Meningkatkan nilai tambah lobster melalui pengolahan dan pengemasan.

\section{b. Nelayan Memiliki Kewajiban}

- Menyediakan tenaga kerja.

Meskipun tidak semua kriteria dapat terpenuhi secara sempurna mengingat kemitraan yang berjalan masih bersifat tradisional, tetapi hubungan kemitraan yang berlangsung lebih mendekati pada pola kemitraan KOA. Yang menjadi dasar pertimbangannya adalah nelayan memperoleh input (sarana dan prasaran penangkapan), modal dalam bentuk biaya operasional serta adanya jaminan pasar berupa bantuan penjualan. Untuk nelayan yang memiliki hak penuh (hak A sampai G) termasuk dalam kategori nelayan yang menggunakan pola kemitraan KOA. Ini terjadi dikarenakan ada masukan input yang diberikan pedagang berupa sarana dan prasarana tangkap. Dengan pola ini maka nelayan akan lebih sulit untuk beralih kepada pedagang lain. Ini disebabkan karena adanya unsur "kepercayaan" yang umumnya akan sulit untuk dilanggar oleh nelayan. Namun dengan pola ini nelayan akan relatif sulit untuk mandiri. Ini terjadi karena pada prinsipnya, guna mempertahankan "aset" (nelayan) pedagang akan berupaya untuk tidak memberi ruang pada nelayan untuk memiliki input pribadi.

\section{Pola Kemitraan Dagang Umum}

Kemitraan yang terbentuk dapat digolongkan kedalam pola kemitraan dagang umum jika memenuhi kriteria sebagai berikut:

\section{a. Pedagang Memiliki Kewajiban}

- Memasarkan lobster nelayan mitra ke perusahaan mitra

- Memberikan jaminan harga lobster yang diperjual-belikan

- Menentukan kualitas lobster yang dapat dijual nelayan mitra pada perusahaan mitra

\section{b. Nelayan Memiliki Kewajiban}

- Memasok lobster pada pedagang

Pada pola kemitraan ini hubungan antara nelayan dengan pedagang akan jauh lebih sederhana dibanding pola kemitraan sebelumnya yaitu pola kemitraan KOA. Dalam pola ini nelayan tidak akan memperoleh input dari 
pedagang berupa perahu, mesin, jaring atau bahan bakar melainkan hanya sebatas hubungan jual beli dan jaminan bahwa setiap lobster yang dijual akan selalu dibeli oleh pedagang yang bersangkutan. Nelayan yang termasuk dalam kategori pola kemitraan dagang umum adalah nelayan yang memiliki jenis hak yang kedelapan yakni sebatas bantuan penjualan. Meskipun dalam hubungan kemitraan antara nelayan dan pedagang tidak terdapat jaminan harga namun hubungan kemitraan yang terjalin lebih mendekati untuk dikatakan sebagai pola kemitraan dagang umum. Ketentuan kualitas diberlakukan oleh pedagang kepada nelayan sesuai dengan permintaan pedagang besar yang akan membeli. Umumnya ketentuan kualitas yang diberlakukan antara lain:

1. Lobster tidak boleh dalam kondisi kaki patah lebih dari 2,

2. Cangkang lobster tidak boleh dalam keadaan lunak, dan

3. Lobster harus dalam kondisi hidup.

Melalui pola kemitraan dagang umum nelayan akan memiliki ruang gerak yang lebih bebas. Ini dikarenakan dalam pola kemitraan ini nelayan hampir tidak memiliki hutang pada pedagang. Satu hal lagi yang menjadi ciri dalam pola kemitraan dagang umum adalah perlunya modal usaha yang besar. Berdasarkan uraian tersebut dapat ditarik suatu kesimpulan bahwa kemitraan tradisional yang terjalin antara nelayan dengan pedagang lebih mengarah pada 2 pola kemitraan antara lain: pola kemitraan Kerjasama Operasional Agribisnis (KOA) dan pola kemitraan Dagang Umum. Oleh karena itu upaya memperkuat posisi tawar nelayan dalam sistem kemitraan menurut Susilawati (2005); Karto (2006) salah satunya melalui penguatan modal usaha.

\section{SIMPULAN}

Simpulan dari penelitian ini yaitu pola kemitraan yang terjalin antara nelayan dengan pedagang pengumpul yang menjual lobster pada UD Edi Koto yakni Kerjasama Operasional Agrbisnis (KOA) dan pola kemitraan Dagang Umum. Pola kemitraan KOA menjadi lebih dominan dibanding pola dagang umum. Dengan pola kemitraan dagang umum akan lebih menguntungkan pedagang.

Implikasinya kemitraan antara nelayan dengan pedagang ataupun pedagang dengan UD Edi Koto masih perlu dibenahi, melalui pembuatan kontrak kerjasama secara tertulis. Melalui kontrak tertulis maka segala ketentuan harga, bagi hasil, serta hal-hal lain yang terkait dengan hubungan kemitraan menjadi jelas dan transparan sehingga memberikan keuntungan bagi kedua pihak. Selain itu dalam pelaksanaan kemitraan ini perlu adanya campur tangan pemerintah untuk memberikan masukan serta menjadi kontrol selama kemitraan berlangsung sehingga menjamin hubungan kemitraan dapat berjalan sesuai dengan yang diharapkan. 


\section{DAFTAR PUSTAKA}

Darwis, V, Endang Lestari H, dan Supena Friyatno. 2006. Revitalisasi Kelembagaan Kemitraan Usaha Dalam Pembangunan Agribisnis Hortikultura di Provinsi Sumatera Utara. Forum Penelitian Agroekonomi Vol.24 No.02. hal.123-134. Pusat Analisis Sosial Ekonomi dan Kebijakan Pertanian. Bogor.

Hafsah, 1999. Kemitraan Usaha: Konsep dan Strategi. Pustaka Sinar Harapan. Jakarta.

Karto. 2006. Strategi Pengembangan Agribisnis Perikanan Tangkap di Kota Singkawang Propinsi Kalimantan Barat. Tesis Program Psacasarjana Manajemen dan Bisnis IPB. Bogor (tidak dipublikasikan)

Kasryno dan Pranaji, 1984. Kemitraan Saat ini dan di Masa di Sektor Pertanian. Badan Penelitian dan Pengembangan Pertanian. Departemen Pertanian.

Saptana dan Ashari.2007. Pembangunan Kemitraan Berkelanjutan melalui Kemitraan Usaha. Jurnal Litbang Pertanian, 26 (4). Hal 123-130. Bogor.

Sumardjo et al, 2004. Teori dan Praktek Kemitraan Agribisnis. Penebar Swadaya. Jakarta.

Suradisastra, 1999. Peran Pemerintah Dalam Pemacuan Industrialisasi Pertanian. Dalam Dinamika Inovasi Ekonomi dan Kelembagaan Pertanian. PSE Badan Penelitian Pengembangan Pertanian. Departemen Pertanian.

Susilawati, MR. 2005. Strategi Pengembangan Agribisnis Perikanan Tangkap di Kabupaten Pesisir Selatan Propinsi Sumatera Barat.Tesis Program Pascasarjana Manajemen dan Bisnis - IPB. Bogor. 